Makalah ini merupakan versi preprint dari paper kami yang dipresentasikan dalam Seminar Nasional Geografi III yang diselenggarakan oleh Fakultas Geografi UGM pada tanggal 03 November 2019 di Yogyakarta.

\title{
Kualitas Air Sungai-sungai Alogenik di Kawasan Karst Gunungsewu, Kabupaten Gunungkidul pada Musim Kemarau
}

\author{
M Widyastuti ${ }^{1,2}$, Ahmad Cahyadi ${ }^{1,2}$, Tjahyo Nugroho Adji ${ }^{1,2}$, Setyawan Purnama ${ }^{1}$, Febby Firizqi ${ }^{1}$, \\ Muhammad Naufal ${ }^{1}$, Fajri Ramadhan ${ }^{1}$, Indra Agus Riyanto ${ }^{3}$, Muhammad Ridho Irshabdillah ${ }^{1}$ \\ Email: m.widyastuti@geo.ugm.ac.id, ahmadcahyadi@geo.ugm.ac.id \\ ${ }^{1}$ Departemen Geografi Lingkungan, Fakultas Geografi, Universitas Gadjah Mada \\ ${ }^{2}$ Kelompok Studi Karst Fakultas Geografi, Universitas Gadjah Mada \\ ${ }^{3}$ Magister Pengelolaan Pesisir dan Daerah Aliran Sungai (MPPDAS), Fakultas Geografi, UGM
}

\begin{abstract}
ABSTRAK
Sumberdaya airtanah di kawasan karst diimbuh oleh dua sistem utama, yakni sistem alogenik dan sistem autogenik. Imbuhan alogenik adalah imbuhan airtanah di kawasan karst yang berasal dari luar kawasan karst. Imbuhan ini memiliki kerentanan terhadap pencemaran yang tinggi karena merupakan sistem terbuka. Namun demikian, imbuhan alogenik memiliki peranan yang besar dalam menyuplai airtanah di kawasan karst karena kuantitasnya yang besar. Penelitian ini bertujuan untuk menganalisis kualitas air pada sungai-sungai alogenik yang ada di Kawasan Karst Gunungsewu, Kabupaten Gunungkidul. Penelitian dilakukan pada musim kemarau di saat sungai bawah tanah menjadi sangat penting karena merupakan satu-satunya sumber air yang masih dapat dimanfaatkan. Pengambilan sampel dilakukan di lima lokasi yaitu Sistem Sungai Alogenik Sumurup, Kalisuci, Tumbul, Kalimati dan Seropan. Analisis kualitas air dilakukan berdasarkan baku mutu air (PP nomor 82 tahun 2001 dan berdasarkan pada standar kualitas air yang disusun oleh Todd dan Mays pada Tahum 2005). Penilaian tingkat pencemaran pada penelitian ini didasarkan pada Metode Storet. Kualitas air pada musim kemarau sungai-sungai alogenik di Kawasan Karst Gunungsewu, Kabupaten Gunungkidul terdiri dari kelas I sampai dengan IV. Klasifikasi tingkat pencemaran di lokasi kajian adalah cemar sedang sampai dengan cemar berat.
\end{abstract}

Kata kunci: Sungai Alogenik, Karst Gunungsewu, Kualitas Air, Pencemaran

\section{PENDAHULUAN}

Kawasan karst dikenal memiliki kondisi hidrologi yang unik dengan berkembangnya porositas sekunder akbiat proses pelarutan batuan oleh air (Goldscheider and Drew, 2007; Ford and Williams, 2011). Karakter yang hidrologi unik telah menyebabkan kawasan karst menjadi sumber air bagi banyak masyarakat di seluruh dunia. Ford and Williams (2007) menyebutkan bahwa kawasan karst berparan dalam pemenuhan kebutuhan air bersih untuk sekitar $1 / 4$ penduduk di dunia. Senada dengan hal tersebut, diperkirakan sekitar 100 juta penduduk Tiongkok juga menggunakan air dari kawasan karst untuk memenuhi kebutuhan hidupnya (LaMoreaux , 1991; Leibundgut et al., 1998; Drew, 1999).

Salah satu kawasan karst yang cukup besar di Indonesia adalah Kawasan Karst Gunungsewu. Kawasan karst ini meliputi empat kabupaten (Bantul, Gunungkidul, Wonogiri dan Pacitan) serta tiga provinsi (Daerah Istimewa Yogyakarta, Jawa Tengah dan Jawa Timur). Kawasan ini memiliki sumberdaya air yang melimpah pada mataair dan sungai bawah tanahnya, sehingga dapat dimanfaatkan untuk memenuhi kebutuhan air bersih di sebagian besar Kawasan Karst Gunungsewu dan wilayah di sekitarnya (Suryono, 2006; Adji, 2009).

Ford and Williams (2007) menyebutkan bahwa kawasan karst memiliki sifat "duality of recharge". Maksud dari pernyataan ini adalah bahwa kawasan karst memiliki dua mekanisme pengimbuhan yakni imbuhan alogenik dan imbuhan autogenik. Imbuhan alogenik (Gambar 1) yang dimaksud dalam sistem hidrologi karst adalah semua imbuhan yang berasal dari kawasan non karst dan mengimbuh airtanah di kawasan karst, sedangkan imbuhan autogenik adalah imbuhan yang berasal dari kawasan karst itu sendiri. 
Makalah ini merupakan versi preprint dari paper kami yang dipresentasikan dalam Seminar Nasional Geografi III yang diselenggarakan oleh Fakultas Geografi UGM pada tanggal 03 November 2019 di Yogyakarta.

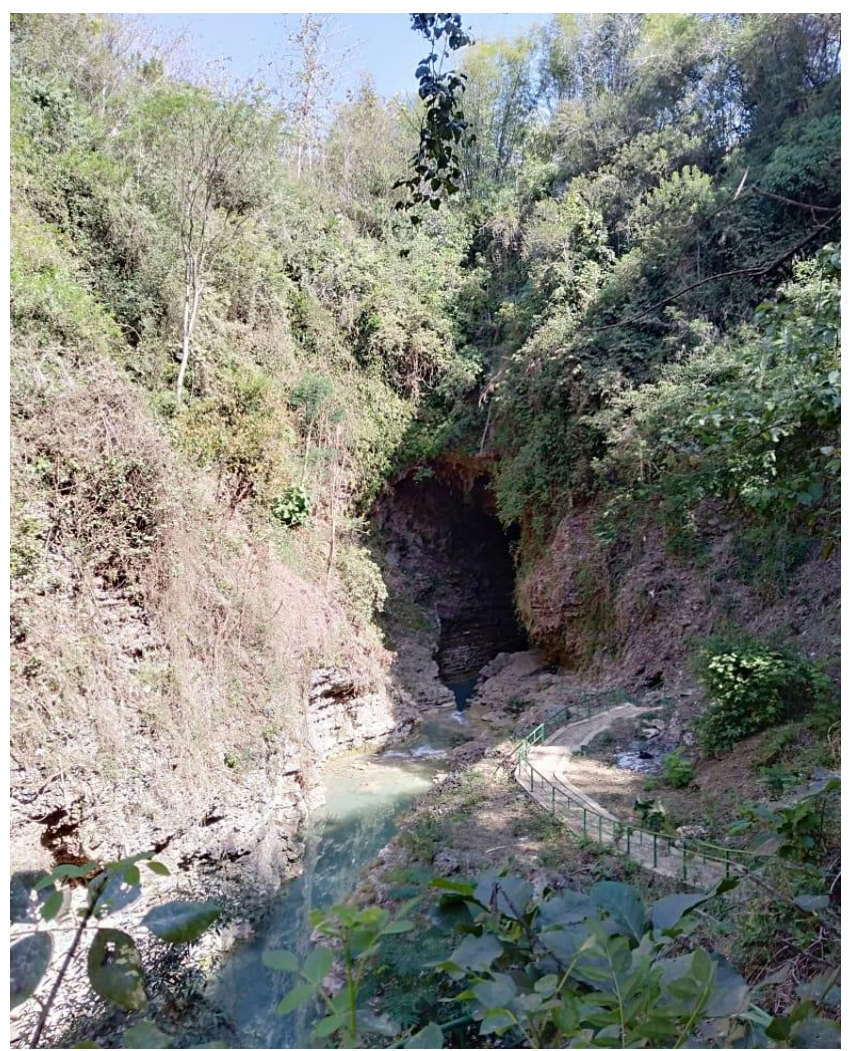

Gambar 1. Swallet Hole Kalisuci, Merupakan Salah Satu Contoh Imbuhan Alogenik di Kawasan Karst Gunungsewu

Imbuhan alogenik memiliki kemungkinan tercemar lebih tinggi dibandingkan dengan imbuhan autogenik karena merupakan sistem terbuka (Gillieson, 1996). Air dari sungai alogenik masuk ke dalam sistem sungai bawah tanah tanpa mengalami penyaringan (terfilter) oleh tanah atau rongga antar butir batuan seperti pada imbuhan autogenik (Adji, 2006; Cahyadi dkk, 2018). Hal ini menyebabkan polutan akan masuk dengan lebih mudah ke dalam sistem sungai bawah tanah (Cahyadi dkk., 2013). Padahal, imbuhan ini alogenik mensuplai airtanah yang banyak ke dalam sistem sungai bawah tanah di Kawasan Karst Gunungsewu (Adji, 2015). Oleh karena itu, disusun penelitian dengan tujuan mengetahui kondisi kualitas air dari sungai alogenik di Kawasan Karst Gunungsewu Kabupaten Gunungkidul. Penelitian ini hanya dilakukan pada musim kemarau saja, meskipun data terkait kualitas air pada musim penghujan disajikan dalam penelitian ini sebagai hasil kajian pustaka.

\section{METODE}

\section{Alat dan Bahan}

Alat dan bahan yang digunakan dalam penelitian ini meliputi:

1. Current meter;

2. Pita ukur;

3. Botol sampel;

4. Seperangkat Komputer;

5. Peta Rupa Bumi Indonesia (RBI) Skala 1:25.000;

6. Peta Geologi Skala 1:100.000;

7. Water quality checker; dan

8. Seperangkat peralatan laboratorium untuk analisis kualitas air.

\section{Lokasi Penelitian dan Pengambilan Data}

Lokasi penelitian merupakan bagian dari sistem hidrogeologi kawasan karst Gunungsewu. Daerah tangkapan air sungai alogenik di lokasi kajian terdapat di dua fisiografi, yaitu Cekungan Wonosari dan Panggung Masif (Gambar 1). Pengambilan sampel dilakukan di lima lokasi yang merupakan sistem sungai alogenik yang terdapat di lokasi kajian (Gambar 2). Kelima sistem ini adalah Sistem Sungai Alogenik Seropan (GK1), Plalar (GK2), Jirak (GK3), Tumbul (GK4), dan Sumurup 
Makalah ini merupakan versi preprint dari paper kami yang dipresentasikan dalam Seminar Nasional Geografi III yang diselenggarakan oleh Fakultas Geografi UGM pada tanggal 03 November 2019 di Yogyakarta.

(GK5). Pengambilan data dilakukan satu kali untuk setiap lokasi pada musim kemarau Tahun 2019, yakni pada bulan Juli 2019.
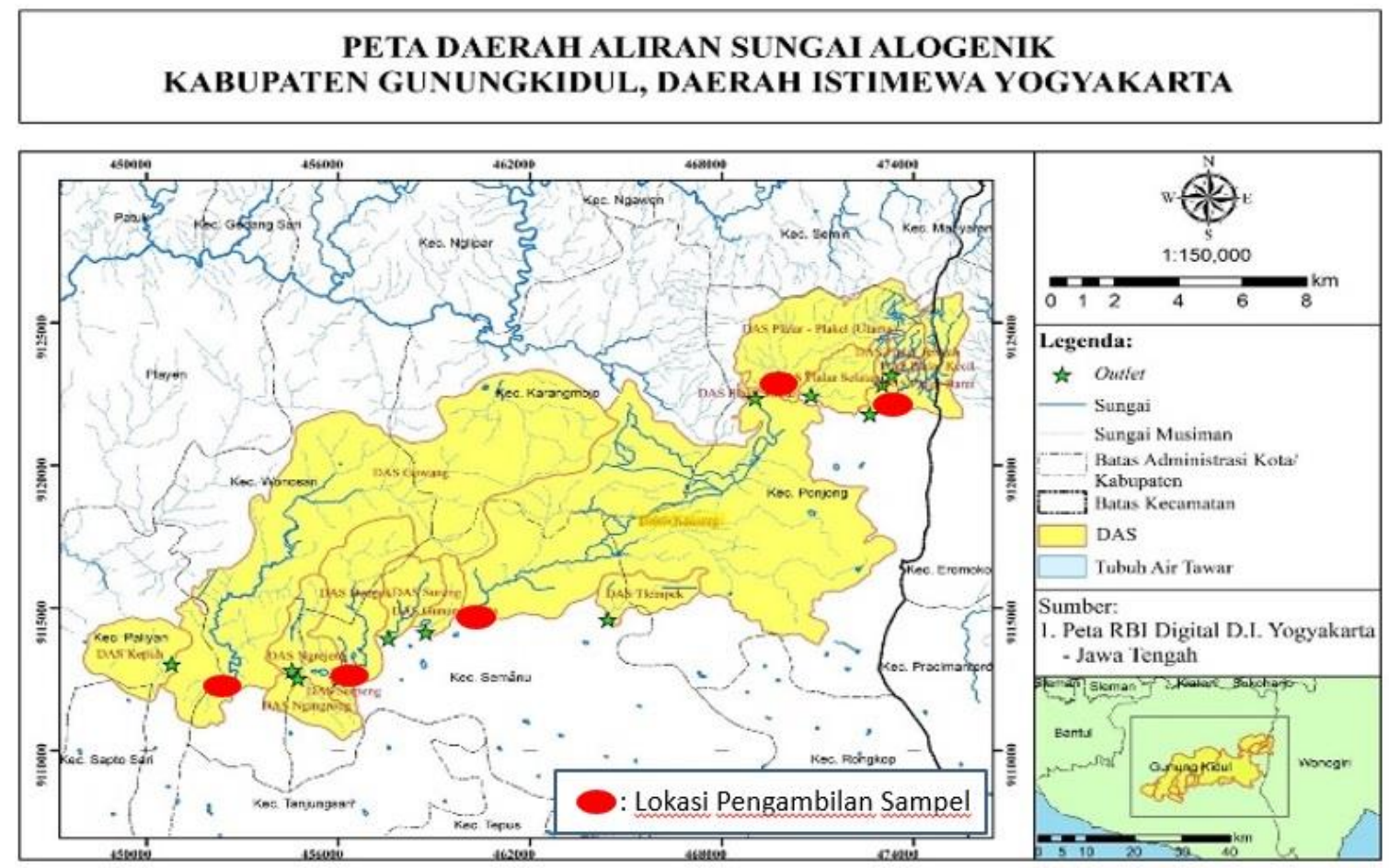

Gambar 1. Lokasi Pengambilan Sampel

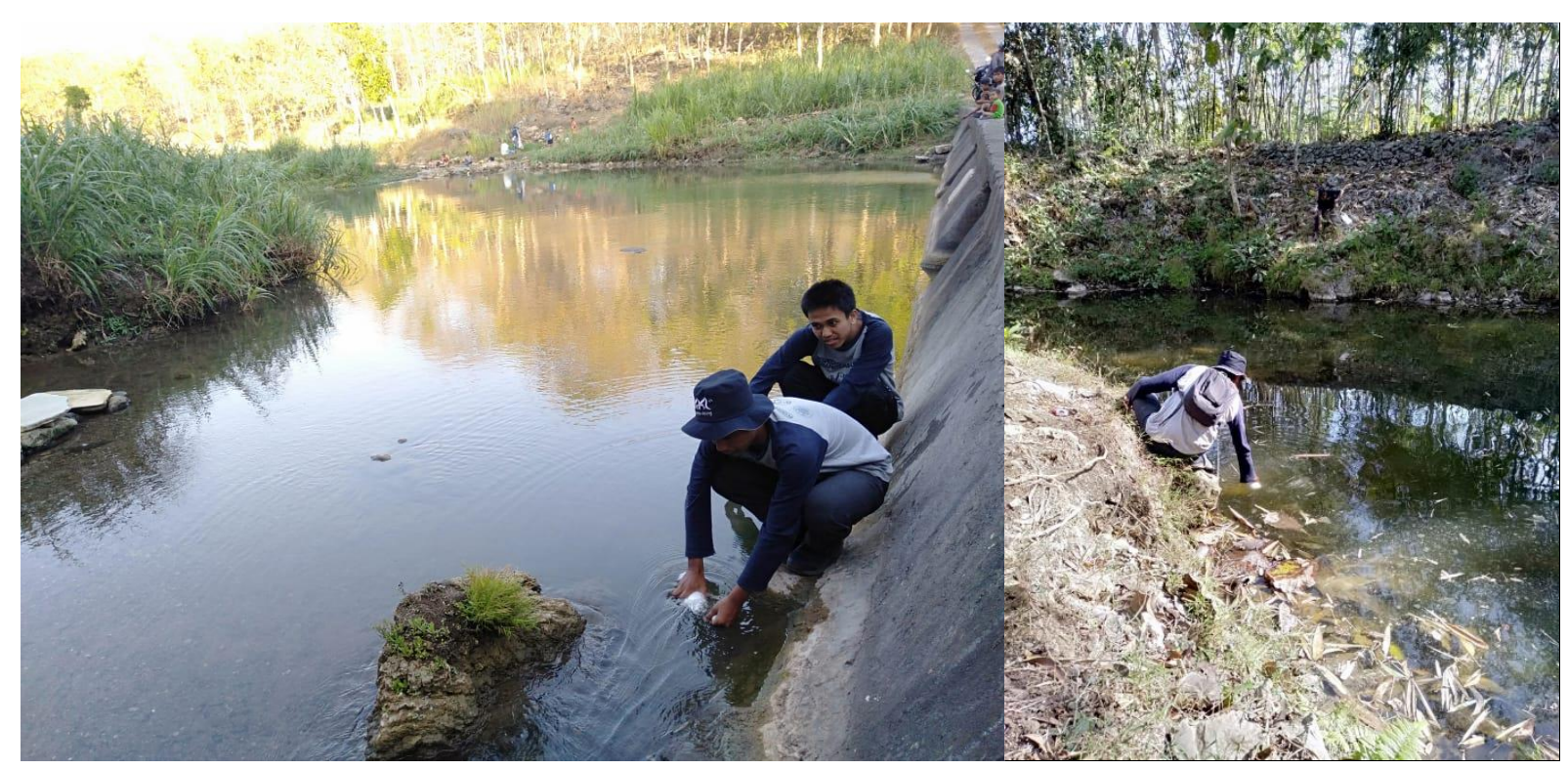

Gambar 2. Pengambilan Sampel Air di Sungai Alogenik Sumurup (Kiri) dan Sungai Alogenik Tumbul (Kanan) pada Bulan Juli 2019

\section{Matode Analisis Data}

Parameter yang dianalisis dalam penelitian ini meliputi $\mathrm{pH}$ (derajat keasaman), Total Disolved Solid (TDS), Biochemical Oxygen Demand (BOD), Chemical Oxygen Demand (COD), Nitrit, Nitrat, Tembaga $(\mathrm{Cu})$, Besi $(\mathrm{Fe})$, Klorida $(\mathrm{Cl})$, Fecal coliform dan Total Coliform. Tujuan pertama dari penelitian ini dilakukan dengan membandingkan hasil analisis laboratorium dengan peraturan pemerintah nomor 82 tahun 2001. Pembandingan ini akan menghasilkan kelas air sesuai dengan PP nomor 82 Tahun 2001 dan hasil kajian Todd and Mays (2005). Kualitas air dinyatakan tercemar pada 
Makalah ini merupakan versi preprint dari paper kami yang dipresentasikan dalam Seminar Nasional Geografi III yang diselenggarakan oleh Fakultas Geografi UGM pada tanggal 03 November 2019 di Yogyakarta.

PP nomor 82 Tahun 2001 jika masuk dalam kategori kelas III atau IV. Hal ini karena kualitas air sungai seharusnya masuk dalam kelas II.

Tingkat pencemaran ditentukan dengan metode storet. Perhitungan dilakukan berdasarkan pada Tabel 1. Parameter yang sesuai dengan baku mutu diberi nilai 0 , sedangkan parameter yang melebihi baku mutu diberi nilai negatif sesuai dengan Tabel 1. Jumlah negatif dari masing-masing lokasi pengambilan sampel kemudian diklasifikasikan berdasarkan klasifikasi yang telah disusun dalam Keputusan Menteri Lingkungan Hidup (KEPMENLH) Nomor 115 Tahun 2003 pada Tabel 2.

Tabel 1. Pemberian Nilai pada Metode Storet

\begin{tabular}{|c|l|c|c|c|}
\hline \multirow{2}{*}{$\begin{array}{c}\text { Jumlah Sampel } \\
\text { yang Diambil }\end{array}$} & \multicolumn{1}{|c|}{ Nilai } & \multicolumn{3}{c|}{ Parameter } \\
\cline { 3 - 5 } & & Fisika & Kimia & -3 \\
\hline \multirow{3}{*}{$<10$} & Maksimum & -1 & -2 & -3 \\
\cline { 2 - 5 } & Minimum & -1 & -6 & -9 \\
\cline { 2 - 5 } & Rata-rata & -3 & -4 & -6 \\
\hline \multirow{2}{*}{$\geq 10$} & Maksimum & -2 & -4 & -6 \\
\cline { 2 - 5 } & Minimum & -2 & -12 & -18 \\
\cline { 2 - 5 } & Rata-rata & -6 & & \\
\hline
\end{tabular}

Sumber: KEPMENLH Nomor 115 tahun 2003

Tabel 2. Klasifikasi Nilai Storet untuk Penentuan Tingkat Pencemaran

\begin{tabular}{|c|c|l|c|l|}
\hline No & Kelas & \multicolumn{1}{|c|}{ Klasifikasi } & Skor & \multicolumn{1}{c|}{ Keterangan } \\
\hline 1 & Kelas A & Baik Sekali & 0 & Memenuhi Baku Mutu \\
\hline 2 & Kelas B & Baik & -10 sampai dengan -1 & Cemar Ringan \\
\hline 3 & Kelas C & Sedang & -30 sampai dengan -11 & Cemar Sedang \\
\hline 4 & Kelas D & Buruk & $\leq-40$ & Cemar Berat \\
\hline
\end{tabular}

Sumber: KEPMENLH Nomor 115 tahun 2003

\section{HASIL DAN PEMBAHASAN}

Kajian serupa dengan penelitian ini pernah dilakukan oleh Adji dkk. (2005). Beberapa parameter melampaui baku mutu berdasarkan pada penelitian tersebut yaitu logam berat seperti Kadmium $(\mathrm{Cd})$, dan Timbal $(\mathrm{Pb})$ serta bakteri coli pada Sungai Alogenik Pentung yang merupakan anak sungai dari Sungai Alogenik Seropan; bakteri coli dan $\mathrm{Pb}$ di Sungai Alogenik Tegoan (anak sungai dari Sungai Alogenik Sumurup); logam berat berupa Kromium (Cr6) dan Timbal (Pb), BOD, bakteri coli pada Sungai Alogenik Sumurup; dan bakteri coli, $\mathrm{Cd}, \mathrm{Pb}$, di Sungai Alogenik Jirak. Kondisi tercemar juga ditemukan pada Gua Bribin dan Resurgence Baron di mana beberapa parameter melebihi standar baku mutu seperti bakteri coli dan COD di kedua lokasi tersebut serta logam berat berupa Kromium (Cr) di Resurgence Baron.

Hasil analisis data yang dilakukan (Tabel 1 dan Tabel 2) menunjukkan bahwa di semua lokasi kajian terjadi pencemaran. Parameter yang masuk dalam kelas IV meliputi BOD (Biological Oxygen Demand), nitrit, klorida, tembaga, dan Fecal coliformform. Nilai BOD yang tinggi menunjukkan banyaknya oksigen yang dibutuhkan oleh organisme untuk mengurai atau menghancurkan zat organik pada lama waktu tertentu. Nilai yang tinggi menunjukkan tingginya bahan organik sebagai pencemar di lokasi kajian. Nilai BOD yang tinggi (kelas IV) terdapat pada Sungai Jirak (GK3) dan Sungai Sumurup (GK5). Tabel 2 juga menunjukkan bahwa Sungai Alogenik Seropan (GK 1) memiliki jumlah parameter yang melebihi baku mutu yang palilng banyak dibandingkan dengan yang lain, yakni enam parameter.

Nitrit yang tinggi ditemukan di Sungai Alogenik Seropan (GK1) dan Sungai Alogenik Sumurup (GK5), sedangkan tembaga ditemukan tinggi di semua sungai alogenik. Nilai klorida yang tinggi di semua sungai alogenik disebabkan karena pencemaran yang berasal dari detergen atau pemutih pakaian. Nampak selama survei, dimusim kemarau masyarakat memanfaatkan sungai untuk mencuci pakaian, sedangkan air minum diperoleh dari sumur dan PDAM. Selain itu, tingginya Fecal coliform terutama di 3 lokasi menunjukkan adanya pencemaran dari limbah feses. 
Makalah ini merupakan versi preprint dari paper kami yang dipresentasikan dalam Seminar Nasional Geografi III yang diselenggarakan oleh Fakultas Geografi UGM pada tanggal 03 November 2019 di Yogyakarta.

Tabel 1. Hasil Analisis Kualitas Air di Lokasi Kajian

\begin{tabular}{|c|c|c|c|c|c|c|}
\hline \multirow[b]{2}{*}{ Parameter } & \multirow[b]{2}{*}{ Satuan } & \multicolumn{5}{|c|}{ Nomor Sampel } \\
\hline & & GK1 & GK2 & GK3 & GK4 & GK5 \\
\hline BOD & $\mathrm{mg} / \mathrm{l}$ & 5,82 & 4,32 & 9,33 & 5,03 & 11,50 \\
\hline COD & $\mathrm{mg} / \mathrm{l}$ & 27,20 & 15,80 & 10,70 & 16,40 & 12,60 \\
\hline $\mathrm{NO}_{3}^{-}$ & $\mathrm{mg} / \mathrm{l}$ & 1,60 & 6,67 & 7,23 & 0,63 & 7,86 \\
\hline $\mathrm{NO}_{2}{ }^{-}$ & $\mathrm{mg} / \mathrm{l}$ & 0,65 & $<0,01$ & $<0,01$ & 0,06 & 0,11 \\
\hline $\mathrm{Cl}^{-}$ & $\mathrm{mg} / \mathrm{l}$ & 9,04 & 10,10 & 11,20 & 17,70 & 19,20 \\
\hline $\mathrm{SO}_{4}^{-}$ & $\mathrm{mg} / \mathrm{l}$ & 30,00 & 24,20 & 25,20 & 27,80 & 31,00 \\
\hline $\mathrm{Mg}^{2+}$ & $\mathrm{mg} / \mathrm{l}$ & 13,60 & 11,70 & 5,80 & 6,80 & 7,80 \\
\hline $\mathrm{HCO}_{3}^{-}$ & $\mathrm{mg} / \mathrm{l}$ & 15,60 & 13,00 & 15,60 & 20,80 & 13,00 \\
\hline $\mathrm{Na}^{+}$ & $\mathrm{mg} / \mathrm{l}$ & 90,52 & 38,46 & 10,46 & 12,04 & 13,44 \\
\hline Kalium $\left(\mathrm{K}^{+}\right)$ & $\mathrm{mg} / \mathrm{l}$ & 1,59 & 1,25 & 1,31 & 2,10 & 4,94 \\
\hline Tembaga & $\mathrm{mg} / \mathrm{l}$ & $<0,03$ & $<0,03$ & $<0,03$ & $<0,03$ & $<0,03$ \\
\hline Besi & $\mathrm{mg} / \mathrm{l}$ & $<0,01$ & $<0,02$ & $<0,01$ & $<0,01$ & $<0,01$ \\
\hline $\mathrm{pH}$ & & 7,8 & 7,6 & 7,8 & 7,7 & 7,8 \\
\hline $\begin{array}{l}\text { Fecal } \\
\text { coliformform }\end{array}$ & MPN/100 ml & $\geq 2.400$ & $1.100,00$ & 4,00 & 460,00 & $\geq 2.400$ \\
\hline Coliform Total & $\mathrm{MPN} / 100 \mathrm{ml}$ & $\geq 2.401$ & $1.100,00$ & 4,00 & 460,00 & $\geq 2.400$ \\
\hline \multirow[t]{5}{*}{ Keterangan: } & \multirow{5}{*}{$\begin{array}{l}: \text { Kelas I } \\
: \text { Kelas II } \\
: \text { Kelas III } \\
: \text { Kelas IV }\end{array}$} & \multicolumn{5}{|c|}{ Berdasarkan Todd and Mays (2005) } \\
\hline & & & \multirow{4}{*}{\multicolumn{4}{|c|}{$\begin{array}{l}\text { : Melebihi Baku Mutu } \\
\text { : Tidak Melebihi Baku Mutu }\end{array}$}} \\
\hline & & & & & & \\
\hline & & & & & & \\
\hline & & & & & & \\
\hline
\end{tabular}

Sumber: Hasil Analisis Laboratorium (2019)

Tabel 2. Hasil Analisis Kualitas Air di Lokasi Kajian

\begin{tabular}{|c|c|c|c|c|c|c|}
\hline \multirow[b]{2}{*}{ Parameter } & \multirow[b]{2}{*}{ Satuan } & \multicolumn{5}{|c|}{ Nomor Sampel } \\
\hline & & GK1 & GK2 & GK3 & GK4 & GK5 \\
\hline BOD & $\mathrm{mg} / \mathrm{l}$ & 5,82 & 4,32 & 9,33 & 5,03 & 11,50 \\
\hline COD & $\mathrm{mg} / \mathrm{l}$ & 27,20 & 15,80 & 10,70 & 16,40 & 12,60 \\
\hline $\mathrm{NO}_{3}^{-}$ & $\mathrm{mg} / \mathrm{l}$ & 1,60 & 6,67 & 7,23 & 0,63 & 7,86 \\
\hline $\mathrm{NO}_{2}^{-}$ & $\mathrm{mg} / \mathrm{l}$ & 0,65 & $<0,01$ & $<0,01$ & 0,06 & 0,11 \\
\hline $\mathrm{Cl}^{-}$ & $\mathrm{mg} / \mathrm{l}$ & 9,04 & 10,10 & 11,20 & 17,70 & 19,20 \\
\hline $\mathrm{SO}_{4}^{-}$ & $\mathrm{mg} / \mathrm{l}$ & 30,00 & 24,20 & 25,20 & 27,80 & 31,00 \\
\hline $\mathrm{Mg}^{2+}$ & $\mathrm{mg} / \mathrm{l}$ & 13,60 & 11,70 & 5,80 & 6,80 & 7,80 \\
\hline $\mathrm{HCO}_{3}^{-}$ & $\mathrm{mg} / \mathrm{l}$ & 15,60 & 13,00 & 15,60 & 20,80 & 13,00 \\
\hline $\mathrm{Na}^{+}$ & $\mathrm{mg} / \mathrm{l}$ & 90,52 & 38,46 & 10,46 & 12,04 & 13,44 \\
\hline Kalium $\left(\mathrm{K}^{+}\right)$ & $\mathrm{mg} / \mathrm{l}$ & 1,59 & 1,25 & 1,31 & 2,10 & 4,94 \\
\hline Tembaga & $\mathrm{mg} / \mathrm{l}$ & $<0,03$ & $<0,03$ & $<0,03$ & $<0,03$ & $<0,03$ \\
\hline Besi & $\mathrm{mg} / \mathrm{l}$ & $<0,01$ & $<0,02$ & $<0,01$ & $<0,01$ & $<0,01$ \\
\hline $\mathrm{pH}$ & & 7,8 & 7,6 & 7,8 & 7,7 & 7,8 \\
\hline $\begin{array}{l}\text { Fecal } \\
\text { coliformform }\end{array}$ & $\mathrm{MPN} / 100 \mathrm{ml}$ & $\geq 2.400$ & $1.100,00$ & 4,00 & 460,00 & $\geq 2.400$ \\
\hline Coliform Total & $\mathrm{MPN} / 100 \mathrm{ml}$ & $\geq 2.401$ & $1.100,00$ & 4,00 & 460,00 & $\geq 2.400$ \\
\hline
\end{tabular}

Keterangan:

: Melebihi Baku Mutu

: Tidak Melebihi Baku Mutu

Sumber: Hasil Analisis Laboratorium (2019) 
Makalah ini merupakan versi preprint dari paper kami yang dipresentasikan dalam Seminar Nasional Geografi III yang diselenggarakan oleh Fakultas Geografi UGM pada tanggal 03 November 2019 di Yogyakarta.

Tabel 3 menunjukkan hasi penilaian kualitas air dari masing-masing sungai alogenik yang dikaji dalam penelitian ini. Warna abu-abu menunjukkan nilai untuk parameter yang melebihi baku mutu, sedangkan warna kuning menunjukkan nilai 0 pada parameter yang tidak melebihi baku mutu. Berdasarkan pada penilaian pada Tabel 3 diketahui bahwa Sungai Alogenik Seropan (GK1) memiliki nilai paling rendah (-48) yang berarti bahwa memiliki tingkat pencemaran yang paling tinggi, sedangkan Sungai Alogenik Jirak dan Sumurup memiliki nilai paling besar (-18) yang menunjukkan bawah kualitas airnya paling bagus di antara sampel yang lain. Tabel 3 juga menunnjukkan bahwa dua sungai alogenik masuk dalam kategori tercemar sedang, dan tiga sungai alogenik yang lain masuk dalam kategori cemar berat.

Tabel 3. Hasil Analisis Kualitas Air di Lokasi Kajian

\begin{tabular}{|c|c|c|c|c|c|c|}
\hline \multirow[b]{2}{*}{ Parameter } & \multirow[b]{2}{*}{ Satuan } & \multicolumn{5}{|c|}{ Nomor Sampel } \\
\hline & & GK1 & GK2 & GK3 & GK4 & GK5 \\
\hline BOD & $\mathrm{mg} / \mathrm{l}$ & -6 & -6 & -6 & -6 & -6 \\
\hline COD & $\mathrm{mg} / \mathrm{l}$ & -6 & 0 & 0 & 0 & 0 \\
\hline $\mathrm{NO}_{3}^{-}$ & $\mathrm{mg} / \mathrm{l}$ & 0 & 0 & 0 & 0 & 0 \\
\hline $\mathrm{NO}_{2}^{-}$ & $\mathrm{mg} / \mathrm{l}$ & -6 & 0 & 0 & 0 & -6 \\
\hline $\mathrm{Cl}^{-}$ & $\mathrm{mg} / \mathrm{l}$ & -6 & -6 & -6 & -6 & -6 \\
\hline $\mathrm{SO}_{4}^{-}$ & $\mathrm{mg} / \mathrm{l}$ & 0 & 0 & 0 & 0 & 0 \\
\hline $\mathrm{Mg}^{2+}$ & $\mathrm{mg} / \mathrm{l}$ & 0 & 0 & 0 & 0 & 0 \\
\hline $\mathrm{HCO}_{3}^{-}$ & $\mathrm{mg} / \mathrm{l}$ & 0 & 0 & 0 & 0 & 0 \\
\hline $\mathrm{Na}^{+}$ & $\mathrm{mg} / \mathrm{l}$ & 0 & 0 & 0 & 0 & 0 \\
\hline Kalium $\left(\mathrm{K}^{+}\right)$ & $\mathrm{mg} / \mathrm{l}$ & 0 & 0 & 0 & 0 & 0 \\
\hline Tembaga & $\mathrm{mg} / \mathrm{l}$ & -6 & -6 & -6 & -6 & -6 \\
\hline Besi & $\mathrm{mg} / \mathrm{l}$ & 0 & 0 & 0 & 0 & 0 \\
\hline $\mathrm{pH}$ & & 0 & 0 & 0 & 0 & 0 \\
\hline $\begin{array}{l}\text { Fecal } \\
\text { coliformform }\end{array}$ & $\mathrm{MPN} / 100 \mathrm{ml}$ & -9 & -9 & 0 & 0 & -9 \\
\hline Coliform Total & MPN/100 ml & -9 & -9 & 0 & 0 & -9 \\
\hline \multicolumn{2}{|l|}{ Nilai Storet } & -48 & -42 & -18 & -18 & -42 \\
\hline \multicolumn{2}{|l|}{ Kelas Storet } & Kelas D & Kelas D & Kelas C & Kelas C & Kelas D \\
\hline \multicolumn{2}{|c|}{ Tingkat Pencemaran } & $\begin{array}{r}\text { Cemar } \\
\text { Berat }\end{array}$ & $\begin{array}{r}\text { Cemar } \\
\text { Berat }\end{array}$ & $\begin{array}{r}\text { Cemar } \\
\text { Sedang }\end{array}$ & $\begin{array}{r}\text { Cemar } \\
\text { Sedang }\end{array}$ & $\begin{array}{r}\text { Cemar } \\
\text { Berat }\end{array}$ \\
\hline
\end{tabular}

Sumber: Hasil Analisis Laboratorium (2019)

Tabel 4 menunjukkan kondisi kualitas air pada musim penghujan (Januari 2019) dan musim kemarau (Juli 2019) pada Sungai Alogenik Jirak. Hasil analisis menunjukkan bahwa kualitas air pada musim kemarau lebih buruk dibandingkan dengan musim penghujan, kecuali pada parameter nitrit dan Fecal coliformform. Kualitas yang baik pada musim penghujan kemungkinan disebabkan terjadinya pengenceran secara alamiah pada tubuh sungai, sehingga kualitas air menjadi semakin baik. Aliran air yang lambat pada musim kemarau menyebabkan akumulasi bahan pencemar pada tubuh sungai. Namun demikian, kegiatan terkait dengan pertanian dan pembuangan sampah termasuk domestik akan banyak terjadi di musim penghujan. Misalnya kegiatan pemupukan akan menyebabkan tingginya nitrit dan nitrat. Apalagi jika pemupukan dilakukan dengan pupuk organik dari kotoran hewan. Pemupukan yang berlebihan akan menyebabkan banyak material pupuk yang terbawa oleh aliran menuju ke sungai. 
Makalah ini merupakan versi preprint dari paper kami yang dipresentasikan dalam Seminar Nasional Geografi III yang diselenggarakan oleh Fakultas Geografi UGM pada tanggal 03 November 2019 di Yogyakarta.

Tabel 4. Perbandingan Kualitas Air di Sungai Alogenik Jirak pada Musim Penghujan dan Musim Kemarau

\begin{tabular}{|c|c|c|c|}
\hline \multirow[b]{2}{*}{ Parameter } & \multirow[b]{2}{*}{ Satuan } & \multicolumn{2}{|c|}{ Kualitas Air Sungai Jirak } \\
\hline & & Penghujan & Kemarau \\
\hline BOD & $\mathrm{mg} / \mathrm{l}$ & 0,86 & 9,33 \\
\hline COD & $\mathrm{mg} / \mathrm{l}$ & 4,69 & 10,70 \\
\hline $\mathrm{NO}_{3}^{-}$ & $\mathrm{mg} / \mathrm{l}$ & 16,26 & 7,23 \\
\hline $\mathrm{NO}_{2}^{-}$ & $\mathrm{mg} / \mathrm{l}$ & 0,042 & $<0,01$ \\
\hline $\mathrm{Cl}^{-}$ & $\mathrm{mg} / \mathrm{l}$ & 0,10 & 11,20 \\
\hline $\mathrm{SO}_{4}^{-}$ & $\mathrm{mg} / \mathrm{l}$ & 24,20 & 25,20 \\
\hline Tembaga & $\mathrm{mg} / \mathrm{l}$ & 0,0371 & $<0,03$ \\
\hline Besi & $\mathrm{mg} / \mathrm{l}$ & 0,02 & $<0,01$ \\
\hline Fecal coliformform & MPN/100 ml & 35,0 & 7,8 \\
\hline
\end{tabular}

Sumber: Cahyadi (2019) dan Hasil Analisis Data (2019)

\section{KESIMPULAN}

Kelas kualitas air pada musim kemarau pada sungai-sungai alogenik di Kawasan Karst Gunungsewu, Kabupaten Gunungkidul meliputi kelas I sampai dengan kelas IV. Parameter yang menunjukkan adanya pencemaran yang berat meliputi BOD, Nitrit, Klorida, Tembaga dan Fecal coliform. Klasifikasi tingkat pencemaran berdasarkan pada Metode Storet di lokasi kajian terdiri atas klasifikasi cemar sedang pada dua sungai alogenik dan klasifikasi cemar berat pada tiga sungai alogenik.

\section{UCAPAN TERIMAKASIH (Acknowledgement)}

Penelitian ini merupakan bagian dari penelitian Hibah Kluster Laboratorium Fakultas Geografi Universitas Gadjah Mada Tahun 2019 dengan judul “Analisis Spasial Kualitas Air Sungaisungai Alogenik Kawasan Karst Gunungsewu, Kabupaten Gunungkidul”. Hibah ini diterima oleh Laboratorium Hidrologi dan Klimatologi Lingkungan dengan penulis paper ini sebagai tim peneliti. Penulis mengucapkan terima kasih kepada pihak Fakultas Geografi UGM yang telah memberikan kesempatan dan memberikan pendanaan untuk penelitian tersebut.

\section{REFERENSI}

Adji, T.N.; Widyastuti, M.; Sudarmadji dan Haryono, E. 2005. Identification of Contaminantion Recharge Area of Bribin-Baron Karst Water System, Gunung Sewu, Indonesia. Laporan Penelitian. Yogyakarta: Fakultas Geografi Universitas Gadjah Mada.

Adji, T. N. 2006. Peranan Geomorfologi dalam Kajian Kerentanan Air Bawah Tanah Karst. Gunung Sewu, Indonesia Cave and Karst Journal, 2(1): 68-79.

Adji, T.N. 2009. Kajian Variasi Spasial-Temporal Hidrogeokimia dan Sifat Aliran untuk Karakterisasi Perilaku Sistem Karst Dinamis (SKD) Sepanjang Sungai Bawah Tanah (SBT) Bribin. Disertasi. Yogyakarta: Universitas Gadjah Mada.

Adji, T.N. 2015. Nilai Ekonomi Air di Daerah Karst. disampaikan dalam Lokakarya Nasional Ekosistem Karst, 16 Desember 2015. Jakarta: Direktorat Bina Pengelolaan Ekosistem Essensial Kemeterian Lingkungan Hidup dan Kehutanan Republik Indonesia.

Cahyadi, A.; Ayuningtyas, E.A. dan Prabawa, B.A. 2013. Urgensi Pengelolaan Sanitasi dalam Upaya Konservasi Sumberdaya Air di Kawasan Karst Gunungsewu Kabupaten Gunungkidul. Indonesian Journal of Conservation, 2(1): 23 - 32.

Cahyadi, A.; Riyanto, I.; Irshabdillah, M.R. and Firizqi, F. 2018. Inventarisasi dan Karakterisasi Sistem Aliran Sungai Alogenik di Kawasan Karst Gunungsewu Kabupaten Gunungkidul. Laporan Penelitian Hibah Dosen Fakultas Geografi UGM. Yogyakarta: Fakultas Geografi, Universitas Gadjah Mada.

Cahyadi, A. 2019. Analisis Hidrogeokimia Sungai Alogenik Jirak, Kabupaten Gunungkidul. Laporan Penelitian. Yogyakarta: Kelompok Studi Karst, Fakultas Geografi, Universitas Gadjah Mada. 
Makalah ini merupakan versi preprint dari paper kami yang dipresentasikan dalam Seminar Nasional Geografi III yang diselenggarakan oleh Fakultas Geografi UGM pada tanggal 03 November 2019 di Yogyakarta.

Drew, D. 1999. Introduction. dalam Drew, D. and Hötzl, H (eds). 1999. Karst Hydrogeology and Human Activities: Impacts, Consequences and Implications. Rotterdam: A.A. Balkema.

Ford, D. dan Williams, P. 2007. Karst Geomorphology and Hydrology. West Sussex: John Wiley and sons, inc.

Ford, D.C. and Williams, P.W. 2011. Geomorphology Underground: The Study of Karst and Karst Processes. dalam Gregory, K.J. and Goudie, A.S (eds). 2011. The SAGE Handbook of Geomorphology. London: SAGE Publications Ltd.

Gillieson, D. 1996. Caves: Processes, Development, and Management. British: Blacwell Publishers.

Goldscheider, N. and Drew, D. (eds) 2007. Methods in Karst Hydrogeology. London: Taylor \& Francis.

LaMoreaux, P.E. 1991. Hystory of Karst Hydrogeological Studies. Proceedings of the International Conference on Environmental Changes in Karst Areas. Universita di Padova, Italia.

Leibundgut, C.; Gunn, J. dan Dassargues, A. 1998. Karst Hydrology. Wallingford, United Kingdom: International Association of Hydrological Science Press.

Suryono, T. 2006. Pengelolaan Sumber Air Bawah Tanah Sungai Bribin. Gunung Sewu. Indonesian Cave and Karst Journal, 2(1): 37-52. 